КОНЦЕПТУАЛЬНІ ЗАСАДИ ДЕРЖАВНОГО РЕГУЛЮВАННЯ

ТА ПІДТРИМКИ ПРОЦЕСІВ КОНКУРЕНТОСПРОМОЖНОГО РОЗВИТКУ АГРАРНОГО СЕКТОРУ В УМОВАХ ГЛОБАЛІЗАЦІї

\title{
CONCEPTUAL PRINCIPLES OF STATE REGULATION AND SUPPORT OF PROCESSES OF COMPETITIVE DEVELOPMENT OF AGRICULTURAL SECTOR IN CONDITIONS OF GLOBALIZATION
}

У статmі запропоновано визначення раціональної підтримки аграрної політики України, яка полягає в комплексі дій і заходів, спрямованих державою на підвищення конкурентоспроможності продукції сільського господарства на внутрішньому та зовнішніх ринках. Визначено, що саме міжнародна торгівля, залучення іноземних інвестицій та розвиток підприємничтва є пріоритетними напрямами національного економічного розвитку. Сорормовано механізм державного регулювання зовнішньої торгівлі, який має бути направлений на зміцнення продовольчої безпеки країни та створення сприятливих умов для закріплення на світових ринках. Визначено зовнішній вектор торгівлі сільськогосподарською продукцією України з країнами Північної Афррики як шлях реалізації експортного потенціалу вітчизняного аграрного сектору, диверсифрікації економіч них ризиків в умовах глобалізації та підвищення геоекономічного статусу нашої держави. Установлено, що в умовах глобалізаці й періодичного виникнення світових орінансових криз зростають можливості несрінансових інструментів залучення іноземних інвестицій, одним із яких є державний брендинг. Розроблено варіанти та напрями національного брендингу України. Найперспективнішою вбачається створення в Україн системи 5/10. Це економічна система заснована на кардинальних реформах, спроможна зробити країну інвестиційно привабливою, відчутно підвищити ї ВВП і рівень життя населення. У стратегічній перспективі слід створити умови для зростання загального рівня продуктивності аграрного сектора на основі гармонійного поєднання різних галузей сільського господарства типів господарств, коли кожне з них займає найбільш притаманну йому ринкову нішу. $A$ цього не можна досягти без формування рівних конкурентних умов в аграрному секторі шляхом реалізації моделі забезпечення конкурентоспроможності аграрного сектору, що базується на реалізації різних стратегій.

Ключові слова: глобалізація, державне регулювання, бренд країни, конкурентоспро- можний розвиток, зовнішньоторговельні відносини.

The article proposes the definition of rational support of the agricultural policy of Ukraine, which consists in a set of actions and measures aimed at the state to increase the competitiveness of agricultural products in domestic and foreign markets. It is determined that international trade, attracting foreign investment and business development are the priority areas of national economic development. A mechanism of state regulation of foreign trade has been formed, which should be aimed at strengthening the country's food security and creating favorable conditions for consolidation in world markets. The external vector of trade in agricultural products of Ukraine with the countries of North Africa as a way of realization of export potential of domestic agricultural sector, diversification of economic risks in the conditions of globalization and increase of geoeconomic status of our state is defined. It is established that in the conditions of globalization and periodic occurrence of world financial crises the possibilities of non-financial instruments of attraction of foreign investments, one of which is state branding, increase. Variants and directions of national branding of Ukraine are developed. The creation of the 5/10 system in Ukraine is considered to be the most promising. This is an economic system based on radical reforms, able to make the country attractive for investment, significantly increase its GDP and living standards. In the strategic perspective, conditions should be created for the growth of the general level of productivity of the agricultural sector on the basis of a harmonious combination of different branches of agriculture and types of farms, when each of them occupies the most inherent market niche. And this cannot be achieved without the formation of equal competitive conditions in the agricultural sector by implementing a model of ensuring the competitiveness of the agricultural sector, based on the implementation of different strategies.

Key words: globalization, state regulation, country brand, competitive development, foreign trade relations.
Постановка проблеми в загальному вигляді. Із посиленням впливу інтеграційних процесів, підпорядкування країни міжнародним тенденціям відбувається зниження ролі держави як регулятора соціально-економічних відносин. Наслідки цього відчуває аграрний сектор, державна підтримка якого в уніфікованій світовій економіці виконує стабілізаційну та стимулювальну функції. В умовах глобалізації та з урахуванням економічної ситуації в державі, пріоритетів у економічній політиці, що формуються 3 огляду на світову панде- мію COVID-19 та боротьбу з нею, прогнозні наслідки відкриття ринку землі, постає необхідність перегляду напрямів державного регулювання, форм і методів підтримки аграрного сектору України.

Аналіз останніх досліджень і публікацій. Зовнішньоторговельні пріоритети розвитку аграрного сектору економіки України в умовах глобалізації досліджені в працях А.С.Гальчинського, В.М.Геєця,Є.Н.Гладунського, О.Л. Даниленка, А.Г. Загороднього, О.Є. Кузьміна, Я.І. Підгородецького, Р.В. Фещура та 
iн. Інституційні засади вдосконалення системи підтримки аграрного сектору у своїх роботах розглядали Н.В. Білецька, А.Г. Борщ, Н.М. Левченко, І.Й. Малий, Б.Й. Пасхавер, I.M. Свідерська, А.С. Шолойко та ін. Однак залишається актуальним питання щодо дослідження та вивчення питання концептуальних засад державного регулювання та підтримки процесів конкурентоспроможного розвитку аграрного сектору в умовах глобалізації.

Метою статті $€$ вивчення засад державного регулювання та проведення аналізу процесів підтримки конкурентоспроможного розвитку аграрного сектору в умовах глобалізації та з огляду на події, що відбуваються протягом останніх двох років в Україні.

Виклад основного матеріалу. За умов неоднозначності трактування цілей аграрної політики України та її основних пріоритетів нами запропоновано визначення раціональної підтримки, яке полягає в комплексі дій і заходів, спрямованих державою на підвищення конкурентоспроможності продукції сільського господарства на внутрішньому та світових аграрних ринках у поєднанні із соціальним захистом населення і розвитком сільських територій. Наведене визначення передбачає, що раціональна підтримка має бути спрямована на підвищення конкурентоспроможності вітчизняної аграрної продукції й надаватися, не викривлюючи торгівлю та не створюючи соціального напруження в суспільстві. Критерієм раціональності державної підтримки може бути залежність між витратами з державного бюджету та зростанням конкурентоспроможності сільськогосподарської продукції на внутрішньому і зовнішньому ринках, а також підвищення добробуту сільського населення.

Необхідність державної підтримки полягає в специфіці національного аграрного сектору, якому притаманні, по-перше, коливання цін на сільськогосподарську продукцію і доходів її виробників, що спричинено природними й економічними чинниками, по-друге, низька еластичність попиту на сільськогосподарську продукцію порівняно з продукцією промисловості, по-третє, залежність сільськогосподарських товаровиробників від промислового, фінансового, торговельного капіталу, який діє за недосконалої конкуренції на противагу аграрним підприємствам, що функціонують в умовах, наближених до чистої конкуренції, по-четверте, неоднозначна регуляторна державна політика, яка не завжди позитивно впливає на розвиток аграрного сектору [6].

Основними важелями державної економічної підтримки, які поширені у світовій практиці й можуть бути використані в Україні в умовах глобалізації та євроінтеграції, мають стати: передання обслуговувальним кооперативам необхідних об'єктів матеріально-технічної бази, що перебувають у державній і муніципальній власності, на засадах довгострокового безпроцентного кредиту або безоплатно; надання пільгових кредитів обслуговувальним кооперативам за схемами, що застосовуються для сільськогосподарських товаровиробників під солідарну відповідальність членів кооперативу; виділення лізингового кредиту кооперативним машинно-технологічним станціям; надання низки пільг оптовим кооперативним ринкам, кооперативним торговим домам та іншим об'єктам ринкової інфраструктури, що функціонують як обслуговувальні кооперативи.

Для усунення недоліків із залученням світового досвіду запропоновано вдосконалити механізм державної підтримки через здешевлення відсоткових ставок за кредитами, який, на відміну від дійсного, передбачатиме диференціацію розміру часткової компенсації відсоткової ставки залежно від пріоритетності цілей використання кредитів, що дасть змогу стимулювати розвиток тих інвестиційних напрямів, які більше потребують державної підтримки (розвиток органічного землеробства, галузі тваринництва, забезпечення основними засобами, впровадження нових технологій, поповнення обігових коштів), строків кредитування (коротко-, середньо- та інвестиційне довгострокове) і позичальників (сільськогосподарських підприємств та дрібних сільськогосподарських товаровиробників).

На концептуальному рівні мають бути змінені підходи до забезпечення фінансовими ресурсами галузі сільського господарства. Основну увагу тут слід зосередити на корпоративних фінансах, підвищенні ролі та значення як невід'ємного чинника функціонування агроформувань у реальних ринкових умовах самофінансування. Мають бути переглянуті відносини між державними й корпоративними фінансами на користь останніх як структур, де формуються фінансові ресурси та розпочинається висхідний потік із подальшим розподілом і перерозподілом на різних рівнях державного управління.

Мають бути замінені форми й методи державної підтримки за безліччю програм і заходів на цілісну систему державної підтримки та захисту галузі з використанням кращого досвіду країн ЄС і задіянням відповідних механізмів та інструментів. Пріоритетами в цьому напрямі мають стати:

- стійке й гарантоване забезпечення населення хлібом і хлібопродуктами та виконання експортних зобов'язань на основі прийняття 
державної цільової програми «Продовольче зерно». В основу забезпечення програми має бути покладено комплексне розв'язання проблеми продовольчого зерна через адресне постачання товарних господарств насіннєвим матеріалом підвищених репродукцій високоврожайних сортів і державний протекціонізм у впровадженні новітніх технологій;

- забезпечення населення молоком та молокопродуктами через прийняття державної цільової програми «Молоко і молокопродукти». Програма має передбачати комплексне розв'язання проблеми, а саме через створення повноцінної кормової бази, забезпечення племінним молодняком високопродуктивних порід; державний протекціонізм і підтримку впровадження сучасних технологій;

- забезпечення населення м'ясом та м'ясопродуктами через прийняття державної цільової програми «М'ясне скотарство і свинарство». Програма має передбачати комплексне розв'язання проблеми, а саме через створення повноцінної кормової бази; забезпечення племінним молодняком високопродуктивних порід; державний протекціонізм і підтримку впровадження сучасних технологій;

- задоволення потреб країни в цукрі через прийняття цільової державної програми «Цукробуряковий комплекс». Програма має передбачати комплексне розв'язання проблеми галузі, а саме забезпечення товарних господарств високоякісним насіннєвим матеріалом, державний протекціонізм у постачанні необхідними матеріальними ресурсами, державну підтримку впровадження високоефективних технології та забезпечення прибутковості галузі й виробництва цукрової сировини [3, с. 67-70].

Сучасна політика підтримки аграрного сектору економіки України характеризується хаотичністю, неоднорідністю структури, постійною зміною векторів та відсутністю стійкої тенденції до зростання. Державне регулювання та національна політика в галузі підтримки аграрного сектору економіки не просто повинні бути дієвою з точки зору показників економічної та соціальної ефективності, а й стимулювати становлення України як аграрної держави. Мають бути замінені наявні форми й методи державної підтримки за безліччю програм і заходів на цілісну систему державної підтримки та захисту галузі з використанням кращого досвіду країн ЄС і використанням відповідних механізмів та інструментів. Для малих та середніх господарств доцільно застосовувати бюджетну підтримку через: збільшення інвестицій у розвиток людського капіталу, соціальної сфери та інженерної інфраструктури; агроекологічні заходи; стимулювання регіональних програм розвитку та специфічних агровиробництв. Зазначене забезпечить розвиток аграрного сектору економіки України як висококонкурентної сфери у світовому вимірі та зростання доходів виробників і сільських жителів.

Із метою врахування дії глобальних процесів необхідною є реалізація системи управління, яка б забезпечила ефективне функціонування економіки держави. Ї̈̈ доцільно розглядати в площині структурно-комплементарного підходу до забезпечення ендогенного функціонування, згідно з яким сталого розвитку національної економіки в контексті впливу глобальних процесів досягають на основі реалізації системи заходів щодо визначення базових векторів дії, стратегічних пріоритетів та інструментів регулювання. 3 урахуванням актуальності досліджуваної теми необхідними $€$ подальші розробки 3 метою визначення теоретичних підходів до вивчення взаємодії між ендо- та екзогенними факторами, вдосконалення інструментарію оцінки цієї взаємодії, а також пошук механізмів управління розвитком економіки відповідно до поточних показників тощо [7, с. 15].

У системі стратегічних цілей зовнішньоекономічної політики України саме міжнародна торгівля, залучення іноземних інвестицій та розвиток підприємництва є пріоритетними напрямами національного економічного розвитку. Отже, концепція сучасного механізму зовнішньоекономічної діяльності держави повинна передбачати наявність таких механізмів, як активізація міжнародної торгівлі, інвестиційна діяльність, сприяння розвитку підприємництва.

Слід констатувати, що на сучасному етапі розвитку зовнішньої торгівлі в Україні ще немає чіткої програми та не простежується виважених дій із боку держави щодо подальшого розвитку та просування вперед. 3 огляду на це, постає надважливе завдання визначити шляхи досягнення кращих позицій у цій сфері. Як найважливішу особливість створення національного механізму державного регулювання зовнішньої торгівлі (рис. 1) в розвинутих країнах виділяємо високу економіко-правову забезпеченість.

Основну законодавчу базу державного регулювання зовнішньої торгівлі в нашій країні вже створено. Однак вона ще є незавершеною, надто фрагментарною. До того ж після ухвалення низки нормативно-правових актів вона постійно змінювалася протягом нетривалого часу, іноді навіть у протилежних напрямах, які не поєднувалися в єдину виважену стратегію. Особливо це стосується таких чутливих сфер 
регулювання, як оподаткування, митні тарифи, процедури реєстрації та ліцензування, правила валютного регулювання. Це не сприяло стабілізації зовнішньоекономічного законодавства і подальшому розвитку зовнішньої торгівлі, не забезпечувало ефективного захисту національного ринку.

Державне регулювання зовнішньоекономічної діяльності аграрного сектору має бути спрямовано на зміцнення продовольчої безпеки країни та створення сприятливих умов для зміцнення позицій України на світових ринках. Головним напрямом державної політики в умовах глобалізації повинен стати економічний протекціонізм. Для її вдосконалення необхідно здійснювати фінансову підтримку вітчизняних експортерів, правове регулювання в зовнішній торгівлі, покращити інформаційне забезпечення зовнішньоекономічної діяльності та надати регіонам певних повноважень у зовнішньоекономічних зв'язках.

Нині є перспективи розширення експорту української агропромислової продукції на ринки країн Північної Африки. Цьому сприяють відносна географічна наближеність України до країн регіону, порівняно швидке транспортуванняукраїнськоїпродукціїтабільшсприятливе співвідношення «ціна - якість» на українське зерно порівняно з продукцією головних країн-конкурентів (США, Канада, Австралія, Росія).

Розширення експортного виробництва агропродовольчої продукції розглядається

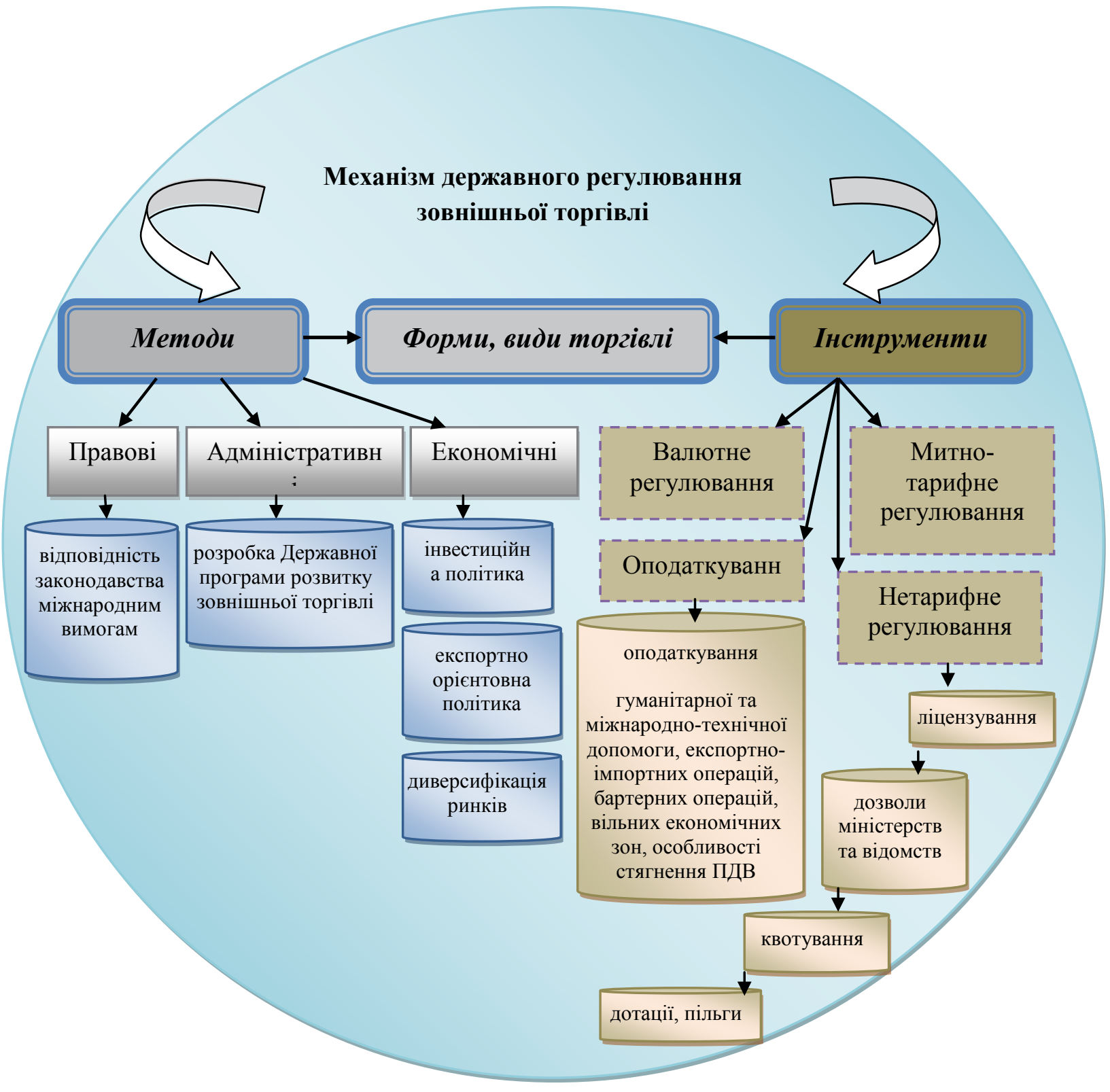

Рис. 1. Механізм державного регулювання зовнішньої торгівлі 
нині чи не єдиним джерелом забезпечення валютних надходжень, що могли б створити необхідні стартові передумови для технічного й технологічного переозброєння вітчизняного аграрного сектору, інтенсифікації виробництва сільськогосподарської й продовольчої продукції загалом. Із набуттям незалежності зовнішньополітичний курс України спрямовано на забезпечення багатовекторних і диверсифікованих відносин із державами, регіонами світу та міжнародними організаціями. Проте Україна досі не спромоглася приділити належну увагу своїй північноафриканській політиці. Тому сьогодні 220-мільйонний ринок цього регіону має стати одним із пріоритетів у комплексі національних економічних інтересів нашої держави. І це пов'язано не тільки з тим, що в Північній Африці сконцентровано значні ресурси енергоносіїв (Алжир, Лівія), фосфатів (Марокко, Туніс), риби (Марокко), а й із тим, що цей регіон $€$ потужним споживачем аграрної продукції. Це величезний ринок, який не можна ігнорувати. Зважаючи на те, що найважливішим складником реальної торговельно-економічної політики України має бути цілеспрямована інтеграція країни у світове господарство на основі нарощування обсягів вивезення готової продукції на світовий ринок, розвиток співробітництва з північноафриканським регіоном має стати стратегічним завданням.

у процесі дослідження нами також виявлено вільний сегмент споживчого ринку країн Північної Африки, що має активний попит у сфері трансферту технологій вирощування: біотехнологій, меліоративних послуг, консультаційних послуг спеціалістів у галузі розробки та впровадження новітніхметодів вирощування сільськогосподарських культур у зоні ризикового землеробства. Зовнішній вектор торгівлі сільськогосподарською продукцією України з країнами Північної Африки - це шлях реалізації експортного потенціалу вітчизняного аграрного сектору, диверсифікації економічних ризиків в умовах глобалізації та підвищення геоекономічного статусу нашої держави.

Глобалізація стирає національні й культурні кордони між державами та символізує тріумфальний хід глобальних корпорацій і глобальних брендів. Потреба мати власний і неповторний образ для держав світу, як і для будь-якої компанії, що виходить на міжнародний простір, постає дуже гостро. Держави і території теж пропонують іноземним компаніям та іноземним громадянам якийсь продукт, а саме себе як центру туризму, прийнятного місця для ведення бізнесу або вкладення коштів, постачальника якісних товарів тощо. Для того, щоб залучити гроші з-за кордону, країна повинна володіти чимось унікальним, оригінальним, упізнаваним, позитивним - усім тим, що формує поняття бренду. Низка країн і територій уже створили такі бренди і тепер за всіма правилами ведуть маркетингові кампанії з просування їх як серед своїх громадян, так і за кордоном.

Міста й країни активно вступають у глобальну боротьбу за привабливість. У світі тисячі міст-близнюків і десятки схожих країн. Для формування бренду країни важливі образи і символи, тому що саме їх сила й нематеріальна цінність відіграє вирішальну роль. Образ, символ, бренд допомагають донести світу, хто ми є, якими бачимо себе, ким хочемо бути. Ріо-де-Жанейро асоціюється із знаменитим карнавалом, Стокгольм із водним фестивалем, Голландія залишається країною тюльпанів, Швейцарія - світовим банком, Париж - законодавцем моди, а Гонконг i Сінгапур - економічним дивом.

Україні теж необхідний свій бренд. Адже бренд знижує невизначеність, забезпечує довіру й визнання. У конкуренції країн за споживачів, туристів та інвестиції перемагає не кількість родовищ із нафтою, заводів і пароплавів, а сила бренду.

В умовах глобалізації й періодичного виникнення світових фінансових криз зростають можливості нефінансових інструментів залучення іноземних інвестицій, одним із яких $€$ державний брендинг. Просування бренду держави сприяє підвищенню конкурентоспроможності національних ідей, товарів, послуг і посиленню її позицій на міжнародній політичній та економічній аренах. Бренд - потужний інструмент захисту фінансових та інших інтересів країн і міст від глобального тиску цивілізації. Він виводить країну на новий економічний рівень, що дуже важливо в умовах кризи, яка охопила світову економіку. Довіра до послуг і товарів, вироблених під брендом, автоматично зростає в кілька разів.

Національна програма «Бренд України» повинна мати широку мету - створити упізнаваний позитивний образ країни у світі, сприяти виникненню й поширенню української національної ідентичності, загального почуття мети і національної гордості, що консолідує країну навколо бренду «Україна».

Україна може запропонувати глобалізованому світові й виграти в боротьбі, тому що має атрибути, які можна репрезентувати світовій громадськості. Бренд України можна формувати на основі позиціонування як цікавої країни з привітними та працьовитими людьми, з унікальною культурою, з високоосвіченим населенням і високопрофесійними кадрами, 
з відомими та цікавими туристичними маршрутами (Крим, Карпати, Дніпро, Дністер, Асканія-Нова, Хортиця), як центр активного розвитку аграрних технологій на родючих землях. Український чорнозем - ще не бренд, який можна продавати, однак про нього знають у світі. За сприятливих умов цей товар можна буде продати дорого.

Завдяки своїм предкам українці володіють унікальним ресурсом - козацьким колоритом. Додаткова перевага - зелений туризм, натуральні продукти харчування, які можна без особливих проблем отримати в будь-якому селі. Неповторний оазис дикої природи в Європі розташовується в Україні - заповідник Асканія-Нова. На 33 тис. га ошатного парку живуть 18 видів ссавців, причому не тільки місцевих, сюди злітається понад 270 видів птахів. Третина цієї унікальної території становить первозданний степ, якого немає в Європі.

Україні сьогодні як ніколи необхідний бренд, який чітко окреслить риси привабливості наявних ресурсів. Унікальність народів визначає географія, і ми унікальні насамперед тим, що живемо на вічному всесвітньому перехресті цивілізацій, релігій і культур. Світу Україна цікава як своїми сучасними досягненнями, так й історичною й культурною спадщиною. Люди хочуть знати душу народу, характер, емоції, його справжнє життя.

Україна в процесі національного брендингу може обрати будь-який образ, просувати та вкладати кошти в будь-яку галузь національного господарства, позиціонувати будь-який регіон (рис. 2). Але постає запитання: «Що з цього збагатить нашу державу, збільшить її вартість, від якого бренду ВВП на душу населення збільшиться в десятки разів?»

Україна може відновити статус «Житниці Європи» та поступово формувати бренд «Годувальниця світу»; спробувати себе як туристичний майданчик світу, вкладаючи кошти в розвиток інфраструктури Карпат, Криму, розвиваючи зелений туризм; призупинити відтік та активізувати притік «мозку світу» й, відповідно, стати «країною інновацій». Це розглядається нами як можливі сценарії розвитку подій і напрями позиціонування України в глобалізованому світі.

Для формування національного бренду нашій державі слід використовувати досвід країн, які досягли у цій справі позитивних результатів. На сучасному етапі не існує універсальної стратегії формування та просування національного бренду, оскільки країни порівняно нещодавно долучилися до цього процесу. Можливо лише проаналізувати певні принципи й елементи, які ефективно впроваджуються в інших країнах, а також на їхприкладі запропонувати алгоритм стратегії формування та просування національного бренду України.

3 урахуванням досвіду країн, що за порівняно невеликий проміжок часу спромоглися навіть без того потенціалу, який має Україна, стати найбагатшими країнами світу (Гонконг, Сінгапур), для нашої держави найбільш реалістичним і доцільним убачається втілення сценарію з формування та просування бренду «Країна без податків».

Найперспективнішою вбачається створення в Україні системи 5/10. Це економічна система, заснована на кардинальних реформах, спроможна зробити країну інвестиційно привабливою, відчутно підвищити її ВВП і рівень життя населення [1].

Економічна реформа і введення системи 5/10 передбачають такі етапи [1]:

1. Відміна всієї податкової системи України (скасування ПДВ, акцизів і мит) і введення простої зрозумілої системи: 5\% із продажів, які платять споживачі товарів і послуг, і 10\% соціальногоподатку, якіплатять одержувачі доходів.

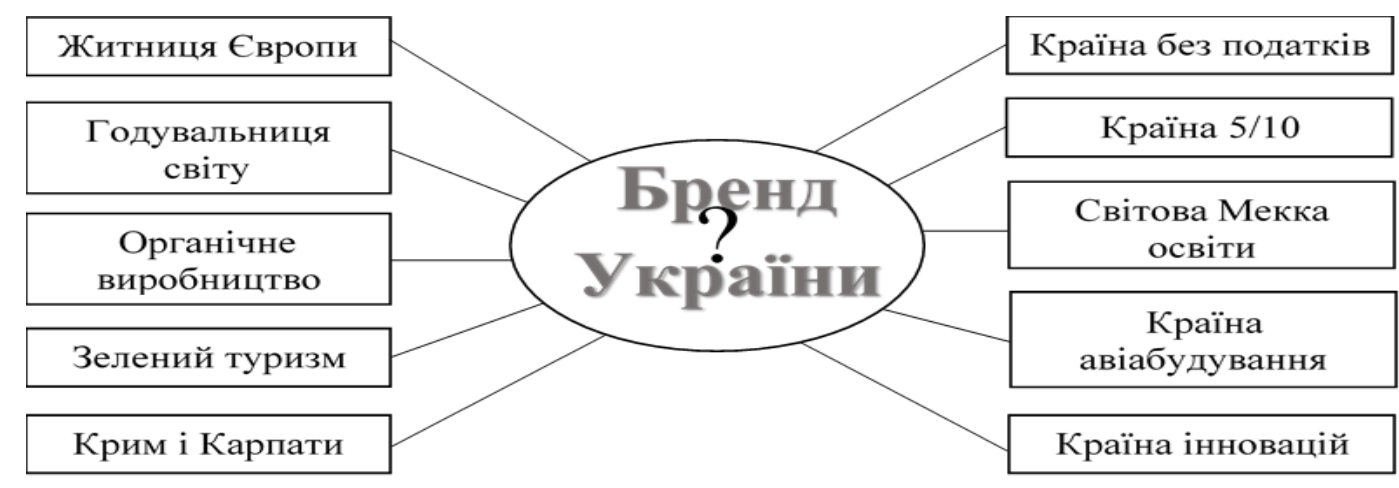

\section{Рис. 2. Можливі варіанти та напрями національного брендингу України}

Джерело: розроблено авторами 
2. Вільний обіг валют. Розрахунки в Україні повинні проводитися в зручній громадянам валюті без будь-яких обмежень.

3. Вільне, тобто без обмежень, проходження товарів і вантажів через митницю, повне відкриття економічних кордонів України. Митний контроль здійснюється тільки з метою виявлення зброї та наркотиків.

В основу системи 5/10 покладено принцип економічної свободи, який поширюється

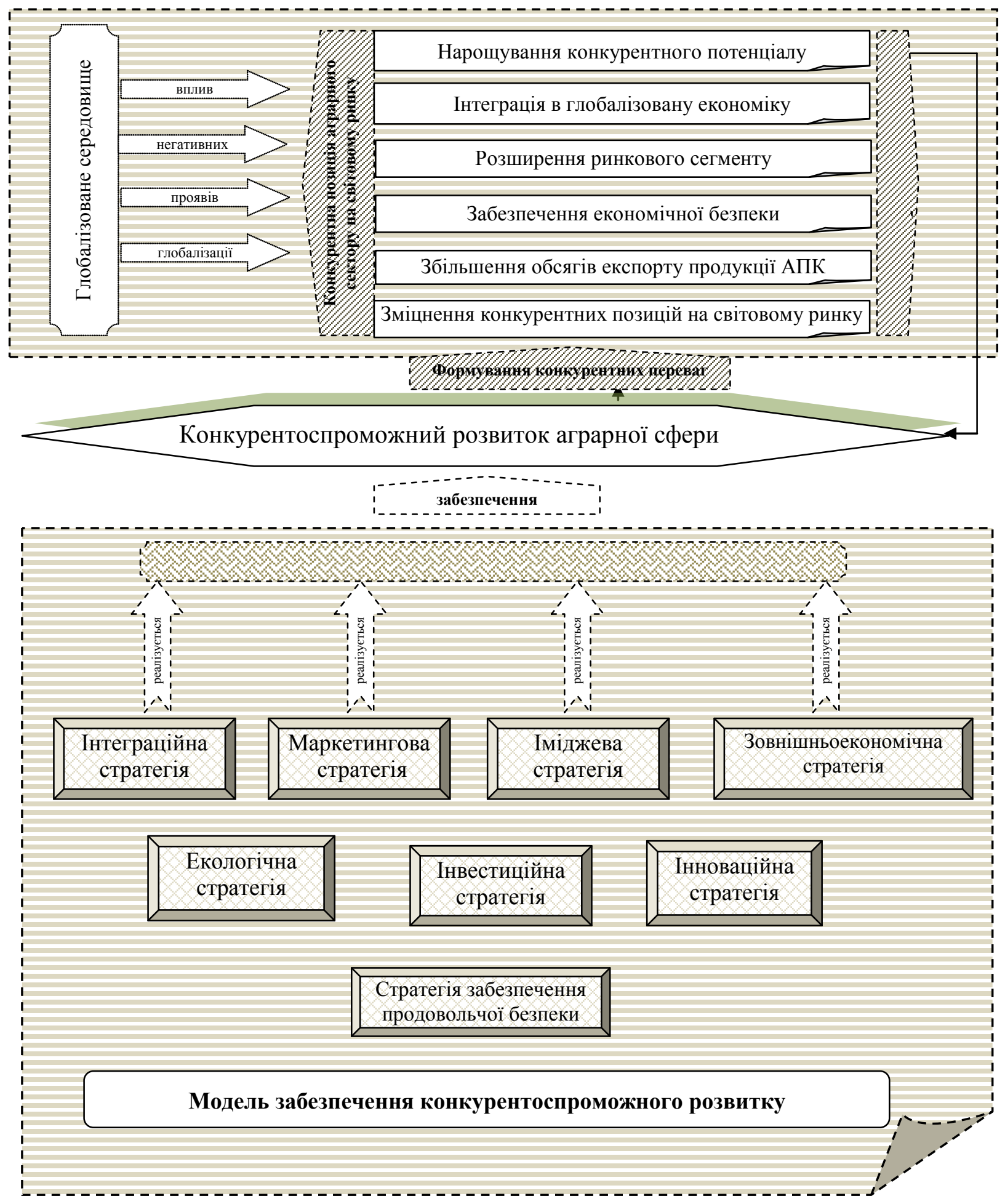

Рис. 3. Парадигма конкурентоспроможного розвитку аграрного сектору економіки в умовах глобалізації

Джерело: сформовано авторами 
на кожного громадянина країни. Ідеться про права і можливості заробляти гроші без відповідних дозволів від державних органів. Низька ділова активність в Україні, бюрократія, корупція є наслідком заплутаної податкової й дозвільної систем. Тому пропонується скасувати та впровадити просту і зрозумілу систему взаємовідносин із державою [1].

У нашій країні процес формування бренду тільки розпочався й характеризується низьким рівнем фінансового та організаційного забезпечення державою. Світове товариство сприймає Україну як країну політичних скандалів, економічної кризи й екологічної загрози. Водночас громадяни країни усвідомлюють необхідність коригування такого сприйняття нашої держави світом. У суспільстві вкорінюється розуміння того, що просування національних інтересів і бренду «Україна» - це стратегічні інвестиції в майбутнє.

Процес створення бренду країни - тривала й кропітка праця спеціалістів багатьох галузей за підтримки населення держави. Ці зусилля слід об'єднати для однієї мети - створення сильного образу України на міжнародній арені, що приведе до прискореного соціально-економічного розвитку держави, конкурентоспроможного розвитку окремих галузей її економіки, зокрема аграрного сектору. Програма національного брендингу повинна бути основою економічного розвитку держави. Національний брендинг стосується найважливіших її сфер - інвестицій, експорту, туризму. Отже, правильно вибудувана й проведена національна кампанія з брендингу країни може суттєво вплинути на економічний розвиток держави й дати йому новий поштовх в умовах глобалізації.

У стратегічній перспективі слід створити умови для зростання загального рівня продуктивності аграрного сектора на основі гармонійного поєднання різних галузей сільського господарства і типів господарств, коли кожне з них займає найбільш притаманну йому ринкову нішу. А цього не можна досягти без формування рівних конкурентних умов в аграрному секторі шляхом реалізації моделі забезпечення конкурентоспроможності аграрного сектору, що базується на реалізації різних стратегій (рис. 3).

Під час розроблення нової моделі конкурентоспроможного розвитку аграрного сектору економіки важливим є оцінка зовнішнього та внутрішнього середовища функціонування, оскільки забезпечує як базу для визначення місії і цілей, так і вибір стратегії поведінки суб'єктів макроекономічних соціально-економічних відносин.
За допомогою аналізу внутрішнього середовища виводиться оцінка стратегічного потенціалу в межах поставленої мети: наскільки за кількістю та якістю ресурсів, станом функцій і проєктів суб'єктів відповідає цільовим вимогам. Таким чином, проводиться аналіз фактичного та нормативного потенціалів, що дозволяє виявити сильні та слабкі сторони підприємства. Аналіз зовнішнього середовища спрямовано на те, щоб виявити можливі конкурентні переваги при ефективному розвитку та функціонуванні, а також те, на які можливі зовнішні загрози можна очікувати. Зовнішнє середовище має у своїй структурі такі два рівні, як мікросередовище та макросередовище. Макросередовище становить сукупність глобальних факторів зовнішнього середовища, які опосередковано впливають на діяльність, а мікросередовище - на прийняття стратегічних рішень.

Тому формування інноваційної стратегії для суб'єктів господарювання аграрного сектору $€$ одним з основних чинників, що забезпечує їх ефективне функціонування в умовах глобальної конкуренції. Основним її складником, узгодженим за цілями і термінами реалізації, є стратегія у сфері створення і використання інновацій.

Висновки. Державне регулювання зовнішньоекономічної діяльності аграрного сектору має бути спрямоване на зміцнення продовольчої безпеки країни та створення сприятливих умов для зміцнення позицій України на світових ринках. Головним напрямом її державної політики в умовах глобалізації має стати економічний протекціонізм. Для її вдосконалення необхідно здійснювати фінансову підтримку вітчизняних експортерів, правове регулювання в зовнішній торгівлі, покращити інформаційне забезпечення зовнішньоекономічної діяльності та надати регіонам певних повноважень у зовнішньоекономічних зв'язках.

Аналіз функціонування аграрного сектору економіки України свідчить, що пошук виходу із ситуації, що склалася, лежить у площині опрацьованої наукової аграрної експорто орієнтованої політики. Пріоритетною метою її має бути забезпечення продовольчої та економічної безпеки країни, перетворення сільського господарства на високорозвинений і конкурентоспроможний на зовнішніх ринках сектор економіки, кардинальне поліпшення демографічної ситуації та соціальних умов на селі. Основними принципами побудови мають бути: пріоритетність розвитку агропромислового комплексу, аграрний протекціонізм, забезпечення гарантій самостійності та убезпечення прямого втручання у виробничу діяль- 
ність сільських підприємців, рівноправність суб'єктів господарювання всіх форм власності.

Ефективна реалізація експортного потенціалу аграрного сектору потребує формування оптимальних товарної та географічної структури експорту продукції. Напрями формування товарної структури мають бути спрямовані на розширення номенклатури експорту й нарощування виробництва товарів, які $€$ найбільш конкурентоспроможними на світових агропродовольчих ринках (соняшникова олія, ячмінь, насіння соняшнику, яловичина, сухе молоко, вершкове масло та сир). Під час розроблення перспективної географічної структури експорту слід ураховувати ризик географічної диверсифікації, що дозволить забезпечити стійкі позиції України на світовому аграрному ринку. Україна повинна зберігати традиційні ринки збуту продукції (країни СНД) та залучати нові перспективні ринки (країни Близького Сходу, Азії, Північної Африки).

Розширення експортного виробництва агропродовольчої продукції розглядається нині чи не єдиним джерелом забезпечення валютних надходжень, що могли б створити необхідні стартові передумови для технічного й технологічного переозброєння вітчизняного аграрного сектору, інтенсифікації виробництва сільськогосподарської й продовольчої продукції загалом.

На підставі розглянутих тенденцій щодо державної підтримки сільського господарства в Україні й інших країнах світу запропоновано збільшення обсягів бюджетних видатків для підтримки галузі залежно від економічної ситуації, зокрема, в кризові роки значення їх різко зростають, а в більш стабільні періоди рівень державної підтримки суттєво знижується. Структура сукупної підтримки сільського господарства також має змінюватися відповідно до економічної ситуації в країні, адже в кризовий період зростає частка програм підтримки виробничого характеру, тоді як у стабільні періоди більше уваги приділяють програмам невиробничого характеру.

Запропоновано вдосконалити механізм державної підтримки через здешевлення відсоткових ставок за кредитами, який, на відміну від дійсного, передбачатиме диференціацію розміру часткової компенсації відсоткової ставки залежно від пріоритетності цілей використання кредитів, що дасть змогу стимулювати розвиток тих інвестиційних напрямів, які більше потребують державної підтримки (розвиток органічного землеробства, галузі тваринництва, забезпечення основними засо- бами, впровадження нових технологій, поповнення обігових коштів), строків кредитування (коротко-, середньо- та інвестиційне довгострокове) і позичальників (сільськогосподарських підприємств та дрібних сільськогосподарських товаровиробників).

Глобалізація, євроінтеграція, посилення міжнародної конкуренції внаслідок стрімких темпів науково-технічного прогресу й активізації інноваційних процесів вимагають нових підходів до соціально-економічного розвитку нашої держави загалом та окремих галузей її економіки зокрема. Успіх економічного зростання та динамічний розвиток відносин з іншими державами світу значно залежить від того, як сформований і просувається на внутрішньому та світовому ринках бренд країни. Цілеспрямовано сформований бренд України сприятиме збагаченню населення, підвищенню інвестиційної привабливості, конкурентоспроможності товарів і послуг, рівноправному входженню в систему світогосподарських зв'язків і дасть змогу посісти гідне місце серед лідерів світової економіки.

\section{ЛІТЕРАТУРА:}

1. Балашов Г. Отмена налогов в Украине. 5.10. URL: http://www.balashov.com.ua/news/1688-otmenanalogov-ukraina-5-10-balashov.html (дата звернення: 28.06.2021)

2. Вишневський Ю. Країна загубленого бренда. Коментарі. 2011. № 4(249).

3. Дем'яненко М.Я. Проблемні питання державної політики фрінансової підтримки сільського господарства. Економіка АПК. 2011. № 7. С. 67-75.

4. Заможне суспільство, конкурентоспроможна економіка, ефрективна держава. Програма економічних реформ на 2010-2014 роки. URL: http://www. president.gov.ua/docs/Programa_reform_FINAL_2.pdf (дата звернення: 19.05.2021).

5. Зубик О. Імідж України: погляд з-за меж. Всеукраїнська експертна мережа URL: http://www. experts.in.ua/baza/analitic/index.php?ELEMENT_ ID=11063 (дата звернення: 19.05.2021).

6. Кирилов Ю.Є. Бренд країни в глобалізованому світі. Херсон : Грінь Д.С., 2013. 156 с.

7. Кирилов Ю.Є. Концептуальні засади конкурентоспроможного розвитку аграрного сектору економіки України в умовах глобалізації. Херсон : ОЛДІ-ПЛЮС, 2015. 420 с.

8. Макух В. В. Україна і країни Магрібу: реалії та перспективи. Актуальні питання двостороннього співробітництва: зб. ст. Одеса : Фенікс, 2010. 244 с.

9. Нагорняк Т.Л. Країна як бренд. Національний бренд «Україна». Стратегічні пріоритети. 2008. № 4 (9). C. 220-228.

10. The Global Innovation Index 2019. URL: https:// www.wipo.int/edocs/pubdocs/en/wipo_pub_gii_2019. pdf (дата звернення: 20.05.2021). 